\title{
Pemberdayaan Ekonomi Transformatif: Pendampingan Manajemen Bisnis pada Jamaah Musholla Putri Manbaul Falah Desa Manyarsidorukun Kecamatan Manyar Kabupaten Gresik
}

\author{
Lilik Rahmawati ${ }^{1}$, Ummiy Fauziyah Laili ${ }^{2}$, Fatikul Himami ${ }^{3}$ \\ ${ }^{123}$ UIN Sunan Ampel Surabaya \\ Email : fatikul.himami@gmail.com
}

\begin{abstract}
Business of fried-chip packaging run by musala's female worshipers is not well managed. This is caused by the lack of business management use. Besides, the technology used is very simple. Accordingly, the business volume and income have been decreasing. It implicates the worshipers' welfare. Economically, they are still dependent on their husbands as the heads of the families. This leads to the economic dependence of women. Additionally, the involvement of musala's female worshipers as the representation of women involvement in economy development of the society becomes decreasing. In these circumstances, social assistance in business management should be conducted. Community service of Manbaul Falah musala's female worshipers uses the approach of ABCD (Asset Based Community Development). This ABCD approach applies some tools, they are inculturation, discovery, definition, design, reflection. The outcome of this community service by assistance in business management results changes in female worshipers community of Manbaul Falah musala who runs the business offried-chip packaging both in the process of assistance and after the process of assistance.
\end{abstract}

Key words: business management, ABCD, woman independence.

\section{A. Pendahuluan}

Tahun 2016 adalah tahun pertama diberlakukannya perdagangan kawasan asia yang disebut dengan ASEAN Economy Community (AEC) atau masyarakat Ekonomi ASEAN (MEA). MEA menyepakati terbentuknya pasar tunggal ASEAN dan basis produksi yang terintegrasi sehingga akan terjadi arus barang dan jasa, investasi, modal, serta tenaga kerja ahli secara bebas ${ }^{1}$.

${ }^{1}$ Muh. Barid Nizaruddin Wajdi, Yuli Choirul Ummah, and Devit Etika Sari, "UKM Development Business Loan," IJEBD (International Journal Of Entrepreneurship And Busimess Development) 1, no. 1 (October 1, 2017): 99-109, accessed November 9, 2017, http://jurnal.narotama.ac.id/index.php/ijebd/article/view/350.

Volume 1, Number 2, November 2017 | 149

Pemberdayaan Ekonomi Transformatif: Pendampingan Manajemen Bisnis pada Jamaah Musholla Putri Manbaul Falah Desa Manyarsidorukun Kecamatan Manyar Kabupaten Gresik

Lilik Rahmawati, Ummiy Fauziy ah Laili, Fatikul Himami 
Sehubungan hal tersebut, tantangan bagi usaha kecil menengah (UKM) adalah upaya untuk terus meningkatkan daya saing melalui peningkatan produktivitas dan kualitas produk. Hal ini sesuai dengan harapan Kementerian Koperasi dan Usaha Kecil Menengah (Kemenkop UKM) yang mendorong usaha kecil meningkatkan kualitas dengan menyesuaikan produknya sesuai Standar Nasional Indonesia (SNI). ${ }^{2}$

Peningkatan daya saing UKM, terlebih UKM yang ada di pedesaan tidak hanya kewajiban pemerintah saja, namun elemen lain seperti perguruan tinggi juga mempunyai peran yang signifikan dalam pengembangan UKM di pedesaan. UKM di pedesaan perlu ditingkatkan daya saingnya mengingat tertinggalnya UKM pedesaan dari teknologi dan manajemen usaha yang profesional $^{3}$. Salah satu peran penting yang bisa dimainkan akademisi perguruan tinggi dalam melaksanakan tridharma perguruan tinggi melalui pengabdian masyarakatadalah dalam bentuk riset, pendampingan kewirausahaan, dan klinik bisnis. Terlebih perguruan tinggi Islam, maka peran penting yang harus diemban akademisi adalah mengintegrasikan misi-misi keIslaman dalam segenap pengabdiannya. Sehubungan dengan hal tersebut, pendampingan usaha kecil di pedesaan termasuk dalam hal ini pendampingan usaha kecil pada jamaah Musholla putri Manbaul Falah oleh akademisi perguruan tinggi Islam menemukan relevansinya.

Sebagian besar jamaah Musholla putri Manbaul Falah Jamaah Desa Manyarsidorukun Kecamatan Manyar mempunyai usaha. Usaha yang dikembangkan diantaranya adalah usaha yang berkaitan dengan hasil laut/ tambak beserta olahannya, usaha di bidang warung nasi/makanan, usaha di bidang penyedian kebutuhan pokok, di bidang konveksi, maupun usaha di bidang jasa. Di antara usaha yang cukup dominan adalah usaha yang berkaitan dengan pengolahan hasil laut maupun tambak.Hal ini bisa dimaklumi karena wilayah Desa Manyarsidorukun berbatasan langsung dengan areal tambak maupun laut. Meski wilayahnya berdekatan dengan sumber bahan baku, namun hal ini tidak membuat usaha pengolahan hasil laut maupun tambak berkembang baik, termasuk dalam hal ini usaha pengemasan kerupuk goreng jamaah Musholla putri Manbaul Falah.

Usaha pengemasan aneka kerupuk goreng yang dikelola jamaah tidak mempergunakan teknologi yang memadai sehingga produktivitasnya rendah dan mengalami kesulitan dalam

${ }^{2}$ News Online, "Peran UMKM hadapi MEA", dikutip dari www.jatengprov.go.id/ diakses 8 Maret 2016

3 M. Ikhsan Setiawan et al., "The Development of the Central Business District (CBD) Based on PublicPrivate Partnership," IJTI (International Journal Of Transportation And Infrastructure) 1, no. 1 (September 29, 2017): 9-14, accessed November 2, 2017, http://jurnal.narotama.ac.id/index.php/ijti/artide/view/327.

Volume 1, Number 2, November 2017 | 150

Pemberdayaan Ekonomi Transformatif: Pendampingan Manajemen Bisnis pada Jamaah Musholla Putri Manbaul Falah Desa Manyarsidorukun Kecamatan Manyar Kabupaten Gresik. 
meningkatkan volume usaha. Karena volume usaha tidak meningkat, maka pendapatan yang dihasilkan juga tidak mengalami peningkatan. Di samping itu akibat teknologi yang terbatas, usaha yang dikelola tidak memperoleh hasil yang berkualitas. Kualitas yang rendah menjadikan usaha kerupuk goreng kemasan kurang mampu bersaing dengan produk sejenis lainnya dan sulit menembus pasaran regional maupun nasional.

Selain teknologi yang kurang memadai, tidak berkembangnya usaha yang dijalankan disebabkan oleh keterbatasan manajemen yang dimiliki dan kemampuan organisasi yang kurang baik. Hal ini disebabkan tidak adanya sistem pencatatan, pelaporan dan evaluasi yang tertib. Dengan demikian pengelolaan tidak termonitor secara pasti.Di samping itu, sistem manajemen yang tercampur dengan manajemen keluarga menjadikan pendapatan usaha sering dimanfaatkan untuk menutup kepentingan keluarga. Oleh karena perempuan desa sebagai pengelola usaha ekonomi produktif perlu diberdayakan pada kemampuan melakukan usaha inovatif, manajemen usaha yang baik, dan kelembagaan organisasi yang baik ${ }^{4}$.

Pemberdayaan perempuan adalah salah satu cara strategis untuk meningkatkan potensi dan peran perempuan baik di ranah publik maupun domestik. Dengan adanya keterlibatan akademisi perguruan tinggi Islam dalam kegiatan pemberdayaan perempuan khususnya perempuan desa, maka diharapkan perempuan desa dapat lebih mengenal potensi yang dimiliki, sehingga dapat menemukan dan menyelesaikan masalah yang dihadapi ${ }^{5}$. Pada akhirnya perempuan diharapkanlebih berdaya dengan usahayang ditekuni sehingga dapat menjadi penyokong terbentuknya masyarakat yang sejahtera dan berperadapan sesuai dengan visi dan misi Islam yang rahmatan lil 'alamin.

\section{B. Riset Pendahuluan dan Basis Teori}

1. Riset Pendahuluan

Riset pendahuluan pada pengabdian ini diantaranya adalah:

a. RB3 dan Pondok Pesantren Sebuah Potret Pemberdayaan Masyarakat Komunitas Pesisir. ${ }^{6}$

\footnotetext{
${ }^{4}$ Muslim Mamulai, Hardianto Djanggih, and Mirnawanti Wahab, "Strength of Evidence of Electronic Media (Teleconference) In The Criminal Justice System," VRIJSPRAAK : International Journal of Law 1, no. 1 (2017): 1-20, accessed November 2, 2017, http://socialscien ce.journal-research.org/index.php/Vrijspraak/article/view/9.

5 Muh Barid Nizaruddin Sekolah Tinggi Agama Islam At-Tahdzib, At-Tahdzib: Jurnal Studi Islam Dan Muamalah., AT-Tahdzib: Jurnal Studi Islam Dan Muamalah, vol. 3, 2016, accessed October 18, 2017, http:/ / ejournal.kopertais4.or.id/mataraman/index.php/tahdzib/artide/view/1864.

${ }^{6}$ Syafi'atul Mardliyah, "RB3 dan Pondok Pesantren Sebuah Potret Pemberdayaan Masyarakat Komunitas Pesisir”, Jurnal Masyarakat Berdaya, Vol.1, No.1 (2011).
} 
b. Pemberdayaan Perempuan Pesisir Melalui Pengembangan Manajemen Komoditas Perekonomian Berbasis Potensi Lokal. (Studi Pemberdayaan Ekonomi Perempuan di Kawasan Pantai Kuwaru, Kecamatan Srandakan, Kabupaten Bantul, DIY) ${ }^{7}$

c. Pondok Pesantren Agribisnia Pemberdayaan Ekonomi Masyarakat Melalui Usaha Agribisnis Berbasis Kerkyatan di Pondok Pesantren Sunan Drajad Paciran Lamongan. ${ }^{8}$

\section{Basis Teori}

Basis teori pada pelaksanaan pengabdian ini meliputi:

\section{a) Pemberdayaan Masyarakat}

Suatu diskursus pemberdayaan selalu akan dihadapkan pada fenomena ketidakberdayaan sebagai titik tolak dari aktivitas pemberdayaan. Ketidakberdayaan yang dialami oleh sekelompok masyarakat telah menjadi bahan diskusi dan wacana akademis dalam beberapa dekade terakhir ini.

Pengertian pemberdayaan menurut Mc Ardle sebagaimana yang dikutip Harry Hikmat mengartikan: pemberdayaan sebagai proses pengambilan keputusan oleh orang orang yang secara konsekuen melaksanakan keputusan tersebut. Orang orang yang telah mencapai tujuan kolektif diberdayakan melalui kemandiriannya, bahkan merupakan "keharusan" untuk lebih diberdayakan melalui usaha mereka sendiri dan akumulasi pengetahuan, ketrampilan dan sumber lainnya dalam rangka mencapai tujuan mereka tanpa bergantung pada pertolongan eksternal. Namun demikian, Mc Ardle mengimplikasikan hal tersebut bukan untuk mencapai tujuan, melainkan makna pentingnya proses dalam pengambilan keputusan. ${ }^{9}$

Istilah keberdayaan dalam konteks masyarakat adalah : kemampuan individu yang bersenyawa dengan invidu-individu lainnya dalam masyarakat untuk membangun keberdayaan masyarakat yang bersangkutan. Memberdayakan masyarakat adalah upaya memperkuat unsurunsur keberdayaan itu untuk meningkatkan harkat dan martabat lapisan masyarakat yang berada dalam kondisi yang tidak mampu dengan mengandalkan kekuatannya sendiri sehingga dapat

${ }^{7}$ E Yuningtyas Setyawati, “Pemberdayaan Perempuan Pesisir Melalui Pengembangan Manajemen Komoditas Perekonomian Berbasis Potensi Lokal. (Studi Pemberdayaan Ekonomi Perempuan di Kawasan Pantai Kuwaru, Kecamatan Srandakan, Kabupaten Bantul, DIY)", Laporan Penelitian, Universitas Atmajaya, Yogyakarta (2011), h. 1

8 Abdul Muhid, "Pondok Pesantren Agribisnis Pemberd ayaan Ekonomi Masyarakat Melalui Usaha Agribisnis Berbasis Kerkyatan di Pondok Pesantren Sunan Drajad Paciran Lamongan”, Jurnal Masyarakat Berdaya, Vol.1, No.1, (2011), h. 23

${ }^{9}$ Harry Hikmat, Strategi Pemberdayaan Masyarakat (Bandung: Humaniora Utama Press, 2010), h. 322

Volume 1, Number 2, November 2017 | 152

Pemberdayaan Ekonomi Transformatif: Pendampingan Manajemen Bisnis pada Jamaah Musholla Putri Manbaul Falah Desa Manyarsidorukun Kecamatan Manyar Kabupaten Gresik 
keluar dari perangkap kemiskinan dan keterbelakangan, atau proses memampukan dan memandirikan masyarakat. ${ }^{10}$

Dalam pengertian lain, pemberdayaan atau pengembangan - atau tepatnya pengembangan sumber daya manusia - adalah : upaya memperluas horison pilihan bagi masyarakat. Ini berarti masyarakat diberdayakan untuk melihat dan memilih sesuatu yang bermanfaat bagi dirinya.Dengan memakai logika ini, dapat dikatakan bahwa masyarakat yang berdaya adalah yang dapat memilih dan mempunyai kesempatan untuk mengadakan pilihanpilihan. ${ }^{11}$

Faktor faktor determinan yang mempengaruhi proses pemberdayaan antara lain, perubahan sistem sosial yang diperlukan sebelum pemberdayaan yang sebenarnya dimungkinkan terjadi. Karena itu, perubahan struktur sosial masyarakat dalam sistem sosial menjadi faktor terpenting dalam melaksanakan pemberdayaan masyarakat. Rojek menekankan sebagaimana yang dikutip Harry Hikmat bahwa sistem sosial yang dimaksud termasuk didalamnya adalah sistem ekonomi dan politik.Webb, mendukung pernyataan Rojek tersebut.Menurutnya, karena hubungan antara individu dan komunitas adalah transaksional, refleksif atau interaktif, sehingga komunitas dapat mempengaruhi perilaku individu. Karena itu, menjadi sangat penting untuk memahami posisi masyarakat yang opresif dalam konteks struktur sosial dan ekonomi dimana mereka hidup. ${ }^{12}$

Jadi, berdasarkan paparan sederhana di atas jelaslah bahwa proses pengembangan atau pemberdayaan pada akhirnya akan menyediakan sebuah ruang kepada masyarakat untuk mengadakan pilihan-pilihan. Sebab, manusia atau masyarakat yang dapat memajukan pilihanpilihan dan dapat memilih dengan jelas adalah masyarakat yang mempunyai kualitas

Sementara itu, pemberdayaan sosial-ekonomi ialah: usaha memberi pengetahuan, keterampilan serta menumbuhkan kepercayaan diri serta kemauan kuat dalam diri seseorang sehingga mampu membangun suatu kehidupan sosial-ekonomi yang lebih baik dengan kekuatan sendiri. Singkatnya, pemberdayaan social ekonomi bermaksud menciptakan manusia swadaya dalam kegiatan social ekonomi. Pemberdayaan sosial-ekonomi ini pada intinya dapat diupayakan melalui berbagai kegiatan antara lain pelatihan, pendampingan, penyuluhan, pendidikan dan keterlibatan berorganisasi demi menumbuhkan dan memperkuat motivasi hidup dan usaha, serta

10 Anwar, Manajemen Pemberdayaan Perempuan (Bandung: Alfabeta, 2007) h. 01

11 Nanih Machendrawaty dkk, Pengembangan Mas yarakat Islam, ( Bandung : Remaja Rosdakarya, 1994 ) h.

42

12 Harry Hikmat, Strategi Pemberdayaan Mas yarakat (Bandung : Humaniora UtamaPress, 2010), h. 14

Volume 1, Number 2, November 2017 | 153

Pemberdayaan Ekonomi Transformatif: Pendampingan Manajemen Bisnis pada Jamaah Musholla Putri Manbaul Falah Desa Manyarsidorukun Kecamatan Manyar Kabupaten Gresik. 
pengembangan pengetahuan dan keterampilan hidup dan kerja. ${ }^{13}$ Terutama di pedesaan, maka pemberdayaan dalam sektor ekonomi merupakan satu strategi pembangunan yang dirangsang bagi peningkatan kehidupan ekonomi dan sosial masyarakat.

\section{b) Pemberdayaan Perempuan}

Realitas ketidakadilan bagi kaum perempuan mulai dari marginalisasi, makhluk Tuhan nomor dua, separoh harga laki-laki, sebagai pembantu, tergantung pada laki-laki dan bahkan sering diperlakukan dengan kasar atau setengah budak.Seakan memposisikan perempuan sebagai kelompok mesyarakat kelas dua, yang berimbas pada berkurangnya hak-hak perempuan termasuk hak untuk mendapatkan pendidikan.Kondisi perempuan di Indonesia dalam bidang pendidikan relatif masih sangat rendah dibandingkan laki-laki.Semakin tinggi tingkat pendidikan, semakin sedikit jumlah perempuan yang mengecapnya. ${ }^{14}$ Sehubungan dengan hal tersebut pemberdayaan perempuan penting untuk dilakukan.

Pemberdayaan perempuan adalah usaha pengalokasian kembali kekuasaan melalui pengubahan struktur sosial. Posisi perempuan akan membaik hanya ketika perempuan dapat mandiri dan mampu menguasai atas keputusan-keputusan yang berkaitan dengan kehidupannya. Terdapat dua ciri dari pemberdayaan perempuan.Pertama, sebagai refleksi kepentingan emansipatoris yang mendorong masyarakat berpartisipasi secara kolektif dalam pembangunan. Kedua, sebagai proses pelibatan diri individu atau masyarakat dalam proses pencerahan, penyadaran dan pengorganisasian kolektif sehingga mereka dapat berpartisipasi. ${ }^{15}$

Pemberdayaan terhadap perempuan adalah salah satu cara strategis untuk meningkatkan potensi perempuan dan meningkatkan peran perempuan baik di domain publik maupun domestik. Hal tersebut dapat dilakukan diantaranya dengan cara: ${ }^{16}$

1) Membongkar mitos kaum perempuan sebagai pelengkap dalam rumah tangga.

Pada zaman dahulu, muncul anggapan yang kuat dalam masyarakat bahwa kaum perempuan adalah konco wingking (teman di belakang) bagi suami serta anggapan "swarga nunut neraka katut" (ke surga ikut, ke neraka terbawa).Kata nunut dan katut

\footnotetext{
13 Yayas an SPES, Pembangunan Berkelanjutan (Jakarta : PT Gramedia Pustaka Utama, 1992), h. 245

${ }^{14}$ Ismah Salman, Keluarga Sakinah dalam Aisyiyah, (Jakarta: PSAP Muhammadiyah, 2005), cet. Ke-1, h.181

15 Zakiyah, Pemberdayaan Perempuan oleh Lajnah Wanita, Jurnal Pengkajian Masalah Sosial Keagamaan, XVII, 01 (Januari-Juni 2010), h.44

16 Ismah Salman, op.cit., h. xiv
} 
dalam bahasa Jawa berkonotasi pasif dan tidak memiliki inisiatif, sehingga nasibnya sangat tergantung kepada suami.

2) Memberi beragam ketrampilan bagi kaum perempuan.

Memberikan keterampilan bagi kaum perempuan agar perempuan dapat produktif dan tidak menggantungkan nasibnya terhadap kaum laki-laki.Berbagai ketrampilan bisa diajarkan, diantaranya: ketrampilan menjahit, menyulam serta berwirausaha dengan membuat kain batik dan berbagai jenis makanan.

3) Memberikan kesempatan seluas-luasnya terhadap kaum perempuan untuk bisa mengikuti atau menempuh pendidikan seluas mungkin.

Hal ini diperlukan mengingat masih menguatnya paradigma masyarakat bahwa setinggitinggi pendidikan perempuan toh nantinya akan kembali ke dapur. Inilah yang mengakibatkan masih rendahnya (sebagian besar) pendidikan bagi perempuan.

Dalam hal peningkatan ekonomi perempuan di Indonesia khususnya di daerah perdesaan, perempuan memiliki keterbatasan dalam menjalankan aktivitasnya, keterbatasan tersebut seperti rendahnya pendidikan, keterampilan, sedikitnya kesempatan kerja, dan juga hambatan ideologis perempuan yang terkait rumah tangga.Selain itu perempuan juga dihadapkan pada kendala tertentu yang dikenal dengan istilah "tripple burden of women", yaitu perempuan harus melakukan fungsi reproduksi, produksi dan fungsi sosial secara bersamaan di masyarakat.Hal tersebut menyebabkan kesempatan perempuan untuk memanfaatkan peluang ekonomi yang ada menjadi sangat terbatas.

Oleh karena itu program pemberdayaan bagi perempuan di bidang ekonomi sangat diperlukan karena pada dasarnya perempuan memiliki potensi yang luar biasa dalam perekonomian terutama dalam pengaturan ekonomi rumah tangga.

Menurut Riant Nugroho, tujuan dari program permberdayaan perempuan adalah $:^{17}$

1) Meningkatkan kemampuan kaum perempuan untuk melibatkan diri dalam program pembangunan, sebagai partisipasi aktif (subjek) agar tidak sekedar menjadi objek pembagunan seperti yang terjadi selama ini,

2) Meningkatkan kemampuan kaum perempuan dalam kepemimpinan, untuk meningkatkan posisi tawar-menawar dan keterlibatan dalam setiap pembangunan baik sebagai perencana, pelaksana, maupun melakukan monitoring dan evaluasi kegiatan.

17 Riant Nugroho dan Randy W, Manajemen Pemberdayaan: Sebuab Pengantar dan Panduan untuk Pemberdayaan Masyarakat, (Jakarta:Elex Media Komputindo, 2007), h. 45

Volume 1, Number 2, November 2017 | 155

Pemberdayaan Ekonomi Transformatif: Pendampingan Manajemen Bisnis pada Jamaah Musholla Putri Manbaul Falah Desa Manyarsidorukun Kecamatan Manyar Kabupaten Gresik 
3) Meningkatkan kemampuan kaum perempuan dalam mengelola usaha skala rumah tangga, industri kecil maupun industri besar untuk menunjang peningkatan kebutuhan rumah tangga, maupun untuk membuka peluang kerja produktif dan mandiri,

4) Meningkatkan peran dan fungsi organisasi perempuan di tingkat lokal sebagai wadah pemberdayaan kaum perempuan agar dapat terlibat secara aktif dalam program pembangunan pada wilayah tempat tinggalnya.

Adapun program-program pemberdayaan perempuan yang ditawarkan menurut Riant Nugroho adalah $:^{18}$

1) Penguatan organisasi kelompok perempuan di segala tingkat mulai dari kampung hingga nasional. Seperti misalnya PKK (Pembinaan Kesejahteraan Keluarga), perkumpulan koperasi maupun yayasan sosial. Penguatan kelembagaan ditujukan untuk meningkatkan kemampuan lembaga agar dapat berperan aktif sebagai perencana, pelaksana, maupun pengontrol,

2) Peningkatan fungsi dan peran organisasi perempuan dalam pemasaran sosial programprogram pemberdayaan. Hal ini penting mengingat selama ini program pemberdayaan yang ada, kurang disosialisasikan dan kurang melibatkan peran masyarakat,

3) Pelibatan kelompok perempuan dalam perencanaan, pelaksanaan dan monitoring semua program pembangunan yang ada. Keterlibatan perempuan meliputi program pembangunan fisik, penguatan ekonomi, dan peningkatan kualitas sumber daya manusia,

4) Peningkatan kemampuan kepemimpinan perempuan, agar mempunyai posisi tawar yang setara serta memiliki akses dan peluang untuk terlibat dalam pembangunan,

5) Peningkatan kemampuan anggota kelompok perempuan dalam bidang usaha (skala industri kecil/rumah tangga hingga skala industri besar) dengan berbagai keterampilan yang menunjang seperti kemampuan produksi, kemampuan manajemen usaha serta kemampuan

\section{c) Pemberdayaan Masyarakat dengan Pendekatan ABCD (Asset Based Community Development)}

Pendekatan ABCD merupakan pendekatan yang mengarah pada pemahaman dan internalisasi asset, potensi, kekuatan, dan pendayagunaannya secara mandiri dan maksimal.Asset 
adalah segala sesuatu yang berharga, bernilai sebagai kekayaan atau perbendaharaan.Segala yang bernilai tersebut memiliki guna untuk memenuhi kebutuhan. ${ }^{19}$

Strategi yang digunakan oleh fasilitator yang dilakukan bersama masyarakat untuk terwujudnya pendampingan adalah:

1) discovery (menemukan),

2) dream (mimpi),

3) design (merancang),

4) define (menetukan), dan

5) destiny (memastikan).

Prinsip pengembangan masyarakat berbasis asset (ABCD) sebagai berikut: setengah terisi lebih berarti, semua punya potensi, partisipasi, kemitraan, penyimpangan positif, berasal dari dalam masyarakat, dan mengarah pada sumber energi. ${ }^{20}$

1) Setengah Terisi lebih Berarti (Half Full Half Empty)

Salah satu modal utama dalam program pengabdian terhadap masyarakat berbasis aset adalah merubah cara pandang komunitas terhadap dirinya. Tidak hanya terpaku pada kekurangan dan masalah yang dimiliki. Tetapi memberikan perhatian kepada apa yang dipunyai dan apa yang dapat dilakukan. ${ }^{21}$

2) Semua Punya Potensi (Nobody Has Nothing)

Dalam konteks ABCD, prinsip ini dikenal dengan istilah "Nobody has nothing". Setiap manusia terlahir dengan kelebihan masing-masing. Tidak ada yang tidak memiliki potensi, walau hanya sekedar kemampuan untuk tersenyum dan memasak air.Semua berpotensi dan semua bisa berkontribusi.

3) Partisipasi (Participation)

Partisipasi adalah suatu keterlibatan mental dan emosi seseorang kepada pencapaian tujuan dan ikut bertanggung jawab di dalamnya. Banyak ahli memberikan pengertian mengenai konsep partisipasi. ${ }^{22}$ Partisipasi berarti peran yang sangat urgen terhadap masyarakat untuk meningkatkan perekonomian baik dalam bentuk pernyataan maupun

${ }^{19}$ Agus Afandi, dkk, Modul Participatory Action Research, (Surabaya: LPPM UIN Sunan Ampel, 2014), h. 308.

${ }^{20}$ Nadhir Salahuddin, dkk, Panduan KKN ABCD UIN Sunan Ampel Surabaya, (LPPM IAIN Sunan Ampel Surabaya, 2015), h. 26.

21 Christopher Dureau, Pembaru dan Kekuatan Lokal Untuk Pembangunan, AustralianCommunity Development and Civil Society Strengthening Scheme (ACCESS) Tahap II, (Agustus 2013), h. 14.

22 Suranto Aw, Komunikasi Sosial Budaya, (Yogyakarta: Graha Ilmu, 2009), hal. 18.

Volume 1, Number 2, November 2017 | 157

Pemberdayaan Ekonomi Transformatif: Pendampingan Manajemen Bisnis pada Jamaah Musholla Putri Manbaul Falah Desa Manyarsidorukun Kecamatan Manyar Kabupaten Gresik. 
dalam bentuk kegiatan dengan memberi masukan pikiran, tenaga, waktu, keahlian, modal dan atau materi, serta ikut memanfaatkan dan menikmati hasil -hasil pembangunan.

4) Kemitraan (Partnership)

Partnership merupakan salah satu prinsip utama dalam pendekatan pengembangan masyarakat berbasis aset (Asset Based Community Development).Partnership merupakan modal utama yang sangat dibutuhkan dalam memaksimalkan posisi dan peran masyarakat dalam pembangunan yang dilakukan. Hal itu dimaksudkan sebagai bentuk pembangunan dimana yang menjadi motor dan penggerak utamanya adalah masyarakat itu sendiri (community driven development). Karena pembangunan yang dilakukan dalam berbagai varinnya seharusnya masyarakatlah yang harus menjadi penggerak dan pelaku utamanya. Sehingga diharapkan akan terjadi proses pembangunan yang maksimal, berdampak empowerment secara masif dan terstruktur. Hal itu terjadi karena dalam diri masyarakat telah terbentuk rasa memiliki (sense of belonging) terhadap pembangunan yang terjadi di sekitarnya.

5) Penyimpangan Positif (Positive Deviance)

Positive Deviance atau (PD) secara harfiah berarti penyimpangan positif. Secara terminologi positive deviance (PD) adalah sebuah pendekatan terhadap perubahan perilaku individu dan sosial yang didasarkan pada realitas bahwa dalam setiap masyarakat meskipun bisa jadi tidak banyak terdapat orang-orang yang mempraktekkan strategi atau perilaku sukses yang tidak umum, yang memungkinkan mereka untuk mencari solusi yang lebih baik atas masalah yang dihadapi daripada rekan rekan mereka itu sendiri. ${ }^{23}$

6) Berawal Dari Masyarakat (Endogenous)

Endogenous dalam konteks pembangunan memiliki beberapa konsep inti yang menjadi prinsip dalam pendekatan pengembangan danpemberdayaan komunitas - masyarakat berbasis asset -kekuatan. Beberapa konsep inti yang dimaksud adalah: ${ }^{24}$

a) Memiliki kendali lokal atas proses pembangunan peningkatan perekonomian.

b) Mempertimbangkan nilai budaya secara sungguh-sungguh.

c) Mengapresiasi cara pandang yang pernah diperoleh masyarakat.

d) Menemukan keseimbangan antara sumber internal dan eksternal.

e) Menuju Sumber Energi (Heliotropic)

23 Edi Suharto, Membangun Masyarakat Memberdayakan Masyarakat, (Bandung: RefikaAditama, 2010), h. 25.

${ }^{24}$ Suntoyo Usman, Pembangunan dan Pemberdayaan Masyarakat, (Yogyakarta: Pustaka Pelajar, 2009), h. 28.

Volume 1, Number 2, November 2017 | 158

Pemberdayaan Ekonomi Transformatif: Pendampingan Manajemen Bisnis pada Jamaah Musholla Putri Manbaul Falah Desa Manyarsidorukun Kecamatan Manyar Kabupaten Gresik 
Energi dalam pengembangan bisa beragam. Di antaranya adalah mimpi besar yang dimiliki oleh komunitas, proses pengembangan yang apresiatif, atau bisa juga keberpihakan anggota komunitas yang penuh totalitas dalam pelaksanaan program. sumber energi ini layaknya keberadaan matahari bagi tumbuhan. Terkadang bersinar dengan terang, mendung, atau bahkan tidak bersinar sama sekali. Sehingga energi dalam komunitas ini harus tetap terjaga dan dikembangkan.

\section{Strategi Pemberdayaan}

Metode pemberdayaan masyarakat melalui pendampingan ini menggunakan metode ABCD.Adapun langkah - langkah pendampingan menempuh beberapa tahap yaitu:

Tahap 1: Mempelajari dan Mengatur Skenario. Dalam Appreciative Inquiry (AI) terkadang disebut 'Define'.Dalam tahap ini tim memanfaatkan waktu untuk mengenal orang-orang dan tempat di mana perubahan akan dilakukan. Artinya Tim melakukan inkulturasi dengan lingkungan dan masyarakat dalam hal ini komunitas majelis taklim muslimat fatayat NU Desa Manyarsidorukun Kecamatan Manyar serta jajaran struktur elitis desa. Tujuan dari tahap ini adalah membangun kepercayaan komunitas dan memfasilitasi kelompok komunitas untuk menjadi agent of change.

Sementara inkulturasi dengan jajaran elitis tujuannya adalah untuk menginformasikanadanya rencana pendampingan kepada komunitas dan menginformasikan tentang keberadaan, kondisi, serta problem usaha yang dikelola ibu-ibu jamaah musholla dan peluangnya dalam penguatan perekonomian keluarga dan desa. Serta perlunya upaya edukasi, pendampingan, dan pelembagaan usaha kecil yang dikelola dalam sebuah kelompok usaha.

Tahap 2: Menemukan Masa Lampau

Pada tahap ini tim berusaha mengungkap (discovery) hal-hal apa yang memberi kemampuan komunitas untuk tiba di titik ini dalam rangkaian perjalanannya dan menelaah sukses dan kekuatan - elemen dan sifat khusus apa yang muncul dari telaah cerita - cerita yang disampaikan oleh komunitas.

Tahap 3: Memimpikan Masa Depan

Tahap ini, tim mendorong komunitas menggunakan imajinasinya untuk membuat gambaran positif tentang masa depan mereka.

Tahap 4: Memetakan Aset

Volume 1, Number 2, November 2017 | 159

Pemberdayaan Ekonomi Transformatif: Pendampingan Manajemen Bisnis pada Jamaab Musholla Putri Manbaul Falab Desa Manyarsidorukun Kecamatan Manyar Kabupaten Gresik 
Pemetaan aset ini bertujuan agar komunitas belajar kekuatan yang sudah mereka miliki sebagai bagian dari kelompok. Apa yang bisa dilakukan dengan baik sekarang dan siapa di antara mereka yang memiliki keterampilan atau sumber daya alam yang ada di desa..Perwakilan kelompok diundang untuk berbagi kekuatan demi kebaikan seluruh kelompok atau komunitas. Pemetaan dan seleksi aset dilakukan dalam 2 tahap:

1) Memetakan aset komunitas atau bakat, kompetensi dan sumber daya sekarang.

2) Seleksi mana yang relevan dan berguna untuk mulai mencapai mimpi komunitas.

Tahap 5: Menghubungkan dan Menggerakkan Aset/Perencanaan Aksi

Tujuan penggolongan dan mobilisasi aset adalah untuk langsung membentuk jalan menuju pencapaian visi. Hasil dari tahapan ini harusnya adalah suatu rencana kerja yang didasarkan pada apa yang bisa langsung dilakukan. Kunci dari tahapan ini, tim meyakinkan komunitas bahwa mereka bisa mulai memimpin proses pembangunan lewat kontrol atas potensi aset yang tersedia dan tersimpan.

Tahap 6: Pemantauan, Pembelajaran dan Evaluasi (refleksi)

Tahap akhir pemberdayaan dengan metode ABCD adalah pemantauan, pembelajaran, dan evaluasi.Pemantauan disertai dengan refleksi yang berbentuk narasi.

\section{Pelaksanaan Pemberdayaan}

Berdasarkan strategi yang digunakan, maka rincian pelaksanaan program dirinci dalam matriks pelaksanaan pendampingan yang ditunjukkan pada tabel 1.1 berikut ini:

Tabel 1.1: Matriks Pelaksanaan Pemberdayaan Masyarakat Melalui Pendampingan Manajemen Usaha Kecil bagi Jamaah Musholla Putri Manbaul Falah

\begin{tabular}{|c|c|c|c|c|}
\hline Tahap & Tujuan & Kegiatan & Jadwal Pelaksanaan & Bukti \\
\hline \multirow[t]{2}{*}{ Inkulturasi } & $\begin{array}{l}\text { Komunitas } \\
\text { mengetahui } \\
\text { maksud } \\
\text { kehadiran Tim } \\
\text { pengabdian }\end{array}$ & $\begin{array}{l}\text { Silaturrahmi } \\
\text { Kepala } \\
\text { Pengurus Mesa, } \\
\text { Fatayat NU, jamaah } \\
\text { musholla putri } \\
\text { Manbaul Falah, dan } \\
\text { tokoh masyarakat }\end{array}$ & $\begin{array}{l}\text { Minggu ke-4 Bulan } \\
\text { September } 2016\end{array}$ & $\begin{array}{l}\text { Catatan } \\
\text { Lapangan } \\
\text { dan foto }\end{array}$ \\
\hline & $\begin{array}{l}\text { Munculnya } \\
\text { kepercayaan } \\
\text { dari komunitas } \\
\text { terhadap tim }\end{array}$ & $\begin{array}{l}\text { Mengikuti majelis } \\
\text { taklim atau kegiatan } \\
\text { yang diadakan } \\
\text { muslimat fatayat } \mathrm{Nu}\end{array}$ & $\begin{array}{l}\text { Minggu ke-1 s.d. } \\
\text { Minggu ke-4 Bulan } \\
\text { Oktober } 2016\end{array}$ & $\begin{array}{l}\text { Catatan } \\
\text { Lapangan } \\
\text { dan foto }\end{array}$ \\
\hline
\end{tabular}




\begin{tabular}{|c|c|c|c|c|}
\hline & \multicolumn{4}{|l|}{ pengabdian } \\
\hline & $\begin{array}{l}\text { Tim } \\
\text { pengabdian, } \\
\text { memfasilitasi } \\
\text { kelompok } \\
\text { masyarakat yang } \\
\text { ada sebagai core } \\
\text { group }\end{array}$ & $\begin{array}{l}\text { Pembentukan core } \\
\text { group }\end{array}$ & $\begin{array}{l}\text { Minggu ke-4 Bulan } \\
\text { Oktober } 2016\end{array}$ & $\begin{array}{l}\text { Susunan } \\
\text { personalia } \\
\text { core group }\end{array}$ \\
\hline Discovery & $\begin{array}{l}\text { Tim pengabdian } \\
\text { mengidentifikasi } \\
\text { asset dan } \\
\text { potensi desa }\end{array}$ & $\begin{array}{l}\text { Melakukan pemetaan } \\
\text { asset melalui fgd dan } \\
\text { interview }\end{array}$ & $\begin{array}{l}\text { Minggu ke-1 Bulan } \\
\text { Nopember } 2016\end{array}$ & $\begin{array}{l}\text { Hasil } \\
\text { pemetaan } \\
\text { fisik, field } \\
\text { note }\end{array}$ \\
\hline \multirow[t]{3}{*}{ Design } & $\begin{array}{l}\text { Mengetahui } \\
\text { asset yang } \\
\text { dimiliki }\end{array}$ & $\begin{array}{l}\text { Mensosialisasikanhasil } \\
\text { pemetaan asset } \\
\text { kepada masyarakat } \\
\text { dan aparat desa } \\
\text { setempat }\end{array}$ & \multirow[t]{3}{*}{$\begin{array}{l}\text { Minggu ke-1 Bulan } \\
\text { Nopember } 2016\end{array}$} & $\begin{array}{l}\text { Foto dan } \\
\text { hasil FGD }\end{array}$ \\
\hline & $\begin{array}{l}\text { Mengidentifikasi } \\
\text { peluang }\end{array}$ & $\begin{array}{l}\text { Mengidentifikasi } \\
\text { peluang dan } \\
\text { kemitraan }\end{array}$ & & \\
\hline & & $\begin{array}{l}\text { Merencanakan } \\
\text { program kerja }\end{array}$ & & $\begin{array}{l}\text { Tabel } \\
\text { program } \\
\text { kerja }\end{array}$ \\
\hline Define & $\begin{array}{l}\text { Terlaksananya } \\
\text { prioritas } \\
\text { program kerja }\end{array}$ & $\begin{array}{l}\text { Memfasilitasi } \\
\text { pelaksanaan program } \\
\text { pilihan masyarakat }\end{array}$ & $\begin{array}{l}\text { Minggu ke-2 Bulan } \\
\text { Nopember } 2016\end{array}$ & $\begin{array}{l}\text { Field note } \\
\text { kegiatan }\end{array}$ \\
\hline Refleksi & $\begin{array}{l}\text { Mengetahui } \\
\text { sejauh mana } \\
\text { Program } \\
\text { membawa } \\
\text { dampak } \\
\text { perubahan }\end{array}$ & $\begin{array}{l}\text { Melakukan } \\
\text { monitoring kegiatan }\end{array}$ & $\begin{array}{l}\text { Minggu ke-2 Bulan } \\
\text { Desember } 2016\end{array}$ & $\begin{array}{l}\text { Hasil } \\
\text { monitoring } \\
\text { dan jurnal } \\
\text { refleksi. }\end{array}$ \\
\hline
\end{tabular}

Dari rincian matriks di atas dapat digambarkan pada Skema Pelaksanaan Pendampingan Manajemen Usaha Kecil bagi Jamaah Musholla Putri Manbaul Falah yang ditunjukkan pada gambar 1.1 berikut ini: 


\section{Gambar 1.1: Skema Pelaksanaan Pendampingan Manajemen Usaha Kecil bagi Jamaah Musholla Putri Manbaul Falah}

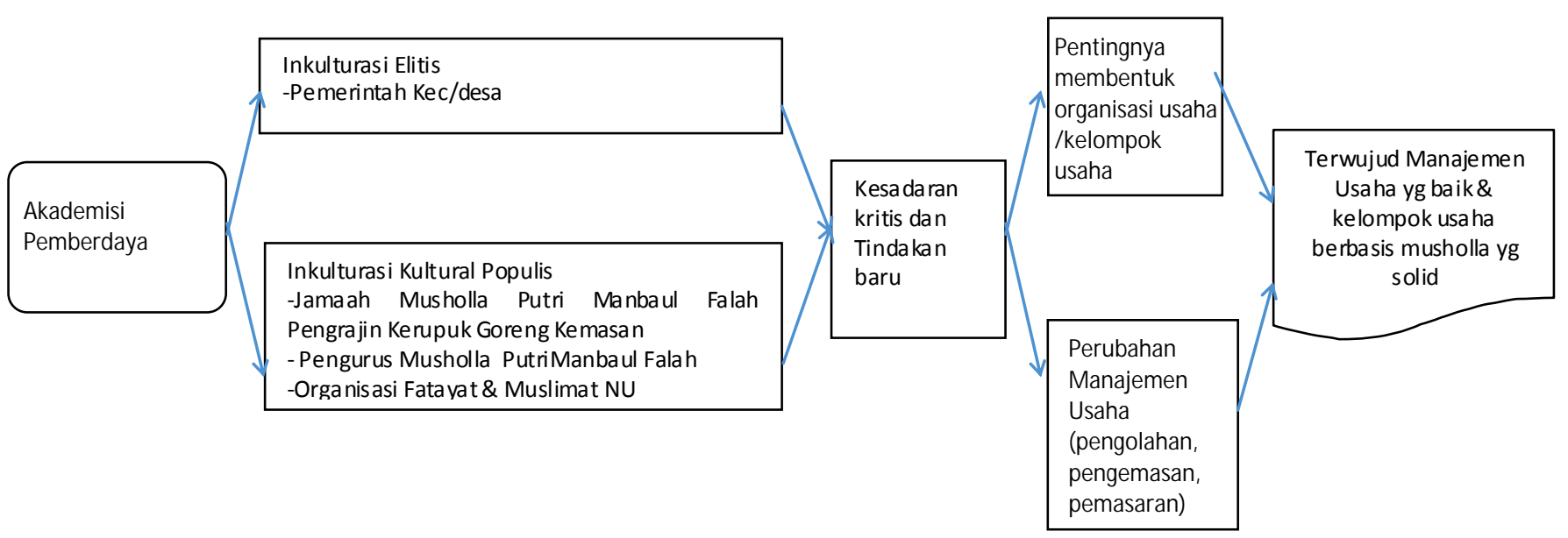

\section{E. Refleksi}

Pada tahapan ini, tim pengabdian ingin mengetahui sejauh mana program membawa dampak perubahan pada komunitas. Oleh karena itu, tim pengabdian melakukan monitoring dan evaluasi. Sebagaimana penjelasan sebelumnya bahwa problem yang dihadapi komunitas dampingan adalah tidak berkembangnya usaha pengolahan hasil tambak atau laut khususnya pada usaha pengemasan kerupuk goreng.Padahal Desa Manyarsidorukun adalah daerah penghasil atau pengolah hasil laut yang cukup potensial mengingat wilayahnya yang berdekatan dengan tambak maupun laut. Berdasarkan analisis tim pengabdiian, permasalahan utama mengapa usaha pengemasan kerupuk goreng tidak berkembang adalah karena komunitas dampingan tidak menerapkan manajemen usaha secara professional dan tidak dibentuknya kelompok usaha. Berdasarkan perumusan bersama antara tim pengabdian, core group yang beranggotakan pengurus Musholla, dan komunitas dampingan maka disepakatilah pilihan program yang akan dilaksanakan yaitu pelatihan manajemen pemasaran dan manajemen keuangan.

Pelatihan manajemen pemasaran dan manajemen keuangan telah dilaksanakan dengan sukses dan mendapat respon yang sangat baik dari komunitas.Oleh karena itu selepas kegiatan pelatihan dilaksanakan, komunitas dampingan secara bersama-sama berkomitmen untuk merubah pengolahan bisnis yang selama ini dijalankan. Alhasil sehubungan dengan manajemen pemasaran, perubahannya dapat diuraikan sebagai berikut. 


\section{Ibu Umi Salamah}

Pada mulanya dalam memasarkan usaha kerupuk goreng, Ibu Umi Salamah mempromosikan lewat acara perkumpulan ibu-ibu PKK di Desa Manyarsidorukun, pada akhirnya usaha pengemasan kerupuk goreng lambat laun dikenal oleh masyarakat. Untuk pemesanan langsung bisa berkunjung ke rumah.Setelah mendapatkan pelatihan manajemen pemasaran, pemasaran kerupuk goreng sekarang tidak terbatas pada Desa Manyarsidorukun saja, namun sudah diperluas sampai ke desa-desa lainnya di Kecamatan Manyar.

Sehubungan dengan pemasaran yang meluas, maka pendapatan yang diterima Ibu Umi Salamah juga bertambah. Oleh karena itu dalam mengelola keuangan, Ibu Umi Salamah telah mampu memisahkan hasil dari penjualan kerupuk dengan keuangan keluarga.Dalam menetapkan harga jual kerupuk juga sudah menggunakan mekanisme penetapan harga sebagaimana materi yang disampaikan dalam pelatihan manajemen keuangan.

Ibu Umi Salamah merasakan betul manfaat dari pelatihan yang diikuti, karena dengan menerapkan manajemen pemasaran dan manajemen keuangan, Ibu Umi Salamah merasakan bisnis yang dijalankan mulai ada peningkatan.

\section{Ibu Hj. Ita}

Pada mulanya dalam memasarkan kerupuk goreng buatannya, Ibu $\mathrm{Hj}$ Ita memasarkannya dengan cara melakukan promosi langsung kepada masyarakat saat ada perkumpulan. Namun sesuai perkembangan zaman, Ibu $\mathrm{Hj}$. Ita juga sudah memanfaatkan pemasaran online melalui BBM, Facebook, WA.

Setelah mengikuti pelatihan manajemen pemasaran, Ibu $\mathrm{Hj}$ Ita lebih memperluas cakupan pemasarannya tidak hanya di wilayah Desa Manyarsidorukun, namun juga di luar Desa Manyar Sidorkun bahkan sampai ke luar kecamatan Manyar. Karena Ibu Hj Ita sudah memanfaatkan pemasaran online melalui BBM, Facebook, dan WA, maka Ibu Hj Ita secara berkala telah memperbaharui postingan-postingan promosinya. Sebelum mengikuti pelatihan, Ibu $\mathrm{Hj}$ Ita jarang sekali memperbaharui postingan-postingan promosinya. Rutinnya Ibu $\mathrm{Hj}$ Ita dalam memperbaharui postingan promosinya, telah dirasakan dampak positifnya. Bagi konsumen lama, mereka ingin mencoba lagi kerupuk yang ditawarkan dan konsumen baru tertarik dengan produk yang diiklankan. 
Sehubungan dengan pemasaran yang meluas, maka pendapatan yang diterima Ibu $\mathrm{Hj}$ Ita juga bertambah. Oleh karena itu dalam mengelola keuangan, Ibu $\mathrm{Hj}$ Ita telah mampu memisahkan hasil dari penjualan kerupuk dengan keuangan keluarga. Hal ini dilakukan agar pendapatan tidak bercampur serta tidak mengalami kesulitan dalam mengetahui nominal laba/rugi. Ibu Hj. Ita juga telah mempu menyisihkan sekitar $40 \%$ dari omset penjualan untuk ditabung.

Dalam menetapkan harga jual kerupuk juga sudah menggunakan mekanisme penetapan harga sebagaimana materi yang disampaikan dalam pelatihan manajemen keuangan.

\section{Ibu Nunul}

Pada mulanya dalam memasarkan kerupuk goreng, Ibu Nunul menjajakan ke rumahrumah.Lambat laun usaha kerupuk goreng sudah dikenal oleh masyarakat Desa Manyarsidorukun. Setelah mengikuti pelatiham manajemen pemasaran, Ibu Nunul lebih memperluas cakupan pemasarannya tidak hanya di wilayah Desa Manyarsidorukun, namun juga di luar Desa Manyar Sidorkun bahkan sampai ke luar kecamatan Manyar. Karena distribusi pemasaran kerupuk goreng sudah meluas sampai ke luar kecamatan Manyar, Ibu Nunul sudah mulai melakukan pemasaran online melalui facebook, WA, maupun BBM.

Meski pemasaran online yang dijalankan masih relatif baru, namun dampak yang dirasakan cukup positif.Ibu Nunul merasakan ada peningkatan omset penjualan.Sehubungan dengan pemasaran yang meluas, maka pendapatan yang diterima Ibu Nunul juga bertambah. Oleh karena itu dalam mengelola keuangan, Ibu Nunul mulai berusaha memisahkan hasil dari penjualan kerupuk dengan keuangan keluarga.Cara sederhana yang dilakukan Ibu Nunul adalah dengan memisahkan dompet yang digunakan untuk menyimpan keuangan keluarga dengan dompet yang dipakai untuk usaha.Cara sederhana ini, terbukti bisa dipakai Ibu Nunul dalam mengukur laba dan omset penjualan.Dalam menetapkan harga jual kerupuk juga sudah menggunakan mekanisme penetapan harga sebagaimana materi yang disampaikan dalam pelatihan manajemen keuangan. 


\section{Ibu Nur}

Pada mulanya dalam memasarkan produknya, Ibu Nur hanya menitipkannya ke warungwarung.Setelah mengikuti pelatihan manajemen pemasaran dan keuangan, ada perubahan paradigm dalam memasarkan kerupuk.Ibu Nur mulai memperluas jangkauan pemasaran tidak cukup hanya dititip-titipkan di warung terdekat, namun juga dititipkan di depot-depot makanan.

Dalam mengelola keuangan, Ibu Nur telah mampu memisahkan Hasil dari penjualan kerupuk dengan keuangan keluarga.Sebagaimana yang dilakukan Ibu Nunul, Ibu Nur juga menggunakan dompet yang berbeda untuk menyimpan uang hasil penjualan dan uang untuk kebutuhan keluarga.Dalam menetapkan harga jual kerupuk juga sudah menggunakan mekanisme penetapan harga sebagaimana materi yang disampaikan dalam pelatihan manajemen keuangan.

\section{Ibu Wiwik}

Pada mulanya dalam memasarkan kerupuk goreng buatannya, Ibu Wiwik memasarkannya dengan cara melakukan promosi langsung kepada masyarakat saat ada perkumpulan. Namun sesuai perkembangan zaman, Ibu $\mathrm{Hj}$. Ita juga sudah memanfaatkan pemasaran online melalui BBM, Facebook, WA. Dalam mengelola keuangan, Ibu Wiwik juga belum mampu memisahkan hasil dari penjualan dengan keuangan keluarga.

Setelah mengikuti pelatihan manajemen pemasaran dan keuangan, Ibu Wiwik mampu memperluas cakupan pemasarannya tidak hanya di wilayah Desa Manyarsidorukun, namun juga di luar Desa Manyar Sidorkun bahkan sampai ke luar Kecamatan Manyar. Karena Ibu Wiwik sudah memanfaatkan pemasaran online melalui BBM, Facebook, dan WA, maka Ibu Wiwik secara berkala telah memperbaharui postingan-postingan promosinya.Sebelum mengikuti pelatihan, Ibu Wiwik jarang sekali memperbaharui postingan-postingan promosinya. Rutinnya Ibu Wiwik dalam memperbaharui postingan promosinya, telah dirasakan dampak positifnya. Bagi konsumen lama, mereka ingin mencoba lagi kerupuk yang ditawarkan dan konsumen baru tertarik dengan produk yang diiklankan.

Upaya ini telah berdampak pada peningkatan pendapatan Ibu Wiwik.Pendapatan per minggu bisa mencapai lebih dari 300.000. Ibu Wiwik juga Bisa menabung kira-kira 40\% dari laba 


\section{Ibu Afifah}

Pada mulanya dalam memasarkan produknya, Ibu Afifah hanya menjualnya di warung sendiri.Setelah mengikuti pelatihan manajemen pemasaran dan keuangan, ada perubahan metode pemasaran kerupuk. Ibu Afifah mulai memperluas jangkauan pemasaran tidak hanya dijual di warungnya sendiri, namun juga dititip-titipkan di warung-warung di Desa Manyarsidorukun dan sekitarnya.

Dalam mengelola keuangan, semula Ibu Afifah masih belum mampu memisahkan hasil dari penjualan kerupuk dengan keuangan keluarga.Namun setelah mengikuti pelatihan manajemen pemasaran dan keuangan, ada perubahan dalam pengolahan keuangan meskipun secara sederhana.Ibu Afifah menggunakan dompet yang berbeda untuk menyimpan uang hasil penjualan dan uang untuk kebutuhan keluarga.Hal ini dilakukan supaya ada kejelasan pendapatan yang diperoleh dari usaha setelah dikurangi biaya produki.Dalam menetapkan harga jual kerupuk juga sudah menggunakan mekanisme penetapan harga sebagaimana materi yang disampaikan dalam pelatihan manajemen keuangan.

\section{Ibu Nur Yaumin}

Pada mulanya dalam memasarkan produknya, Ibu Nur Yaumin hanya menjualnya di warung sendiri dan beberapa warung tetangga.Setelah mengikuti pelatihan manajemen pemasaran dan keuangan, ada perubahan metode pemasarannya.Ibu Nur Yaumin mulai memperluas jangkauan pemasaran tidak cukup hanya dititip-titipkan di warung terdekat, namun juga dititipkan di warung-warung di Desa Manyarsidorukun dan sekitarnya.

Dalam mengelola keuangan, Ibu Nur Yaumin telah mampu memisahkan hasil dari penjualan kerupuk dengan keuangan keluarga.Ibu Nur Yaumin mampu memisahkan pendapatan usaha dengan keuangan keluarga, Ibu Nur Yaumin menggunakan dompet yang berbeda untuk menyimpan uang hasil penjualan dan uang untuk kebutuhan keluarga.Dalam mengelola keuangan, Ibu Nur Yaumin sudah mampu memisahkan hasil dari penjualan dengan keuangan keluarga.Pendapatan dari usaha penjualan kerupuk juga mengalami peningkatan.Setiap minggu Ibu Nur Yaumin memperoleh pendapatan lebih dari 300.000.Dengan pendapatan yang bertambah Ibu Nur Yaumin mampu menyisihkan sebagian pendapatannya untu ditabung. 
Dalam menetapkan harga jual kerupuk juga sudah menggunakan mekanisme penetapan harga sebagaimana materi yang disampaikan dalam pelatihan manajemen keuangan.

Dari paparan di atas, membuktikan bahwa ada perubahan yang positif dari usaha yang dijalankan ibu-ibu jamaah Musholla Manbaul Falah setelah mengikuti pelatihan manajemen pemasaran dan keuangan. Perubahan posistif ini diharapkan tidak berhenti sampai di sini saja, namun juga terus dikembangkan selepas tim pengabdian selesai bertugas. Untuk itu, dalam rangka memantau, mengevaluasi, serta meningkatkan perkembangan usaha ibu-ibu Jama'ah Musholla Manbaul Falah telah disepakati terbentuknya koordinator tim ekonomi Musholla Manbaul Falah. Tim ini diketuai oleh Ibu Hj. Cholishotun Nafsiyah, M.Pdi.Tim inilah yang menjadi inisiasi terbentuknya kelompok usaha.

\section{F. Penutup}

Salah satu peran penting yang bisa dimainkan oleh akademisi perguruan tinggi dalam melaksanakan tridharma perguruan tinggi adalah melalui pengabdian kepada masyarakat.Salah satu bentuk pengabdian yang bisa dilaksanakan untuk perempuan desa adalah melalui pendampingan manajemen bisnis.Kegiatan ini dimaksudkan untuk meningkatkan kesejahteraan dan kemandirian perempuan dalam kaitan keterlibatannya dalam pembangunan masyarakat.Terlebih akademisi perguruan tinggi Islam, maka peran penting yang harus diemban akademisi adalah mengintegrasikan misi-misi keIslaman dalam segenap pengabdiannya. Peran penting ini relevan dengan pendampingan usaha kecil yang dilakukan tim pengabdian masyarakat yang dilaksanakan pada komunitas jama’ah Musholla putri Manbaul Falah.

Pelaksanaan pengabdian pada jama'ah Musholla putri Manbaul Falah Desa Manyarsidorukun Manyar Gresik mendapatkan respon yang baik dari level penentu kebijakan dalam hal ini pimpinan desa yaitu kepala desa dan jajarannya, pimpinan organisasi masyarakat dalam desa yaitu muslimat fatayat NU, serta pada komunitas sendiri.

Dari hasil pengabdian telah tampak adanya hasil yang terukur yang terlihat nyata dalam setiap tools pengabdian yang dilaksanakan. Ada perubahan yang lebih baik.Perubahannya tampak pada dua ranah. Ranah pada saat proses pengabdian dan setelah pengabdian. Saat proses pengabdian, terjadi perubahan pada komunitas yaitu: 
1. Muncul kesadaran akan problem yang dihadapi

2. Muncul kemauan untuk melakukan perubahan

3. Respon, antusiasme dan kerjasama yang baik dalam memberikan informasi untuk kemajuan dan pengembangan usaha selama proses pendampingan.

Sementara itu, perubahan setelah proses pengabdian pada komunitas diantaranya adalah:

1. Mengolah, mengemas, dan melakukan pelabelan produk aneka kerupuk kemasan secara lebih baik disbanding sebelum mengikuti pelatihan

2. Melakukan manajemen usaha yang lebih baik meliputi pencatatan, pelaporan keuangan dan evaluasi bisnis dengan baik

3. Memperluas jangkauan pemasaran aneka kerupuk kemasan berbasis manajemen pemasaran tidak hanya di wilayah Desa Manyarsidorukun tetapi sampai ke luar desa bahkan sampai meluas ke kota.

4. Terbentuk kelompok usaha aneka kerupuk kemasan berbasis majelis musholla sehingga kelompok usaha selain dapat meningkatkan perkembangan bisnis juga diharapkan dapat menjalankan bisnis sesuai prinsip-prinsip etika bisnis Islam. Kelompok usaha ini diketuai oleh Ibu. Hj Cholishotun Nafsiyah.

\section{DAFTAR PUSTAKA}

Afandi, Agus dkk, Modul Participatory Action Research, (Surabaya: LPPM UIN Sunan Ampel, 2014) Anwar, Manajemen Pemberdayaan Perempuan (Bandung: Alfabeta, 2007)

Hikmat, Harry, Strategi Pemberdayaan Masyarakat (Bandung: Humaniora Utama Press, 2010)

Machendrawaty, Nanih, Pengembangan Masyarakat Islam, ( Bandung : Remaja Rosdakarya, 1994)

Mardliyah, Syafi'atul. "RB3 dan Pondok Pesantren Sebuah Potret Pemberdayaan Masyarakat Komunitas Pesisir", Jumal Masyarakat Berdaya, Vol.1, No.1, 2011

Muhid, Abdul. "Pondok Pesantren Agribisnis Pemberdayaan Ekonomi Masyarakat Melalui Usaha Agribisnis Berbasis Kerakyatan di Pondok Pesantren Sunan Drajad Paciran Lamongan”, Jurnal Masyarakat Berdaya, Vol.1, No.1, 2011

News Online, "Peran UMKM hadapi MEA", dikutip dari www.jatengprov.go.id/ diakses 8 Maret 2016

Salahuddin, Nadhir dkk, Panduan KKN ABCD UIN Sunan Ampel Surabaya, (LPPM IAIN Sunan Ampel Surabaya, 2015)

Salman, Ismah, Keluarga Sakinah dalam Aisyiyah, (Jakarta: PSAP Muhammadiyah, 2005), cet. Ke-1. Saptari R, dan Holzner, B. Perempuan Kerja dan Perubaban Sosial: Sebuah Pengantar Studi Perempuan. Jakarta: Pustaka Utama Grafiti, 1997

Setyawati, Yuningtyas "Pemberdayaan Perempuan Pesisir Melalui Pengembangan Manajemen Komoditas Perekonomian Berbasis Potensi Lokal. (Studi Pemberdayaan Ekonomi

Volume 1, Number 2, November 2017 | 168

Pemberdayaan Ekonomi Transformatif: Pendampingan Manajemen Bisnis pada Jamaah Musholla Putri Manbaul Falah Desa Manyarsidorukun Kecamatan Manyar Kabupaten Gresik 
This work is licensed under a Creative Commons

Attribution-ShareAlike 4.0 International License. CC BY SA

Perempuan di Kawasan Pantai Kuwaru, Kecamatan Srandakan, Kabupaten Bantul, DIY)", Laporan Penelitian, Universitas Atmajaya, Yogyakarta 2011

Suharto, Edi, Membangun Masyarakat Memberdayakan Masyarakat, (Bandung: Refika Aditama, 2010) Suranto Aw, Komunikasi Sosial Budaya, (Yogyakarta: Graha Ilmu, 2009).

Usman, Sunyoto, Pembangunan dan Pemberdayaan Masyarakat, (Yogyakarta: Pustaka Pelajar, 2009)

Yayasan SPES, Pembangunan Berkelanjutan (Jakarta : PT Gramedia Pustaka Utama, 1992),

Yeremias, Keban, dan Lele Gabriel. Capacity Building dalam Wacana Pembangunan Kontemporer: Telaah Konseptual dan Implikasinja, 1999

Zakiyah, Daradjad, Pemberdayaan Perempuan oleh Lajnah Wanita, Jurnal Pengkajän Masalab Sosial Keagamaan, XVII, 01 (Januari-Juni 2010)

Mamulai, Muslim, Hardianto Djanggih, and Mirnawanti Wahab. "Strength of Evidence of Electronic Media (Teleconference) In The Criminal Justice System." VRIJSPRAAK : International Journal of Law 1, no. 1 (2017): 1-20. Accessed November 2, 2017. http://socialscience.journal-research.org/index.php/Vrijspraak/article/view/9.

Sekolah Tinggi Agama Islam At-Tahdzib, Muh Barid Nizaruddin. At-Tahd₹ib : Jurnal Studi Islam Dan Muamalah. AT-Tahdrib: Jurnal Studi Islam Dan Muamalah. Vol. 3, 2016. Accessed October 18 ,

2017. http:// ejournal.kopertais4.or.id/mataraman/index.php/tahdzib/article/view/1864.

Setiawan, M. Ikhsan, Agus Sukoco, Iswachyu Dhaniarti, and Cholil Hasyim. "The Development of the Central Business District (CBD) Based on Public-Private Partnership." IJTI (International Journal Of Transportation And Infrastructure) 1, no. 1 (September 29, 2017): 9-14. Accessed November 2, 2017. http://jurnal.narotama.ac.id/index.php/ijti/article/view/327.

Wajdi, Muh. Barid Nizaruddin, Yuli Choirul Ummah, and Devit Etika Sari. "UKM Development Business Loan." IJEBD (International Journal Of Entrepreneurship And Business Development) 1, no. 1 (October 1, 2017): 99-109. Accessed November 9, 2017. http://jurnal.narotama.ac.id/index.php/ijebd/article/view/350. 